\title{
PARAMYLOIDOSIS COMPLICATING MYELOMATOSIS
}

\section{CASE REPORT}

\author{
By K. G. Lowe,* M.D.(St. And.), M.R.C.P. and C. F. Ross, B.Sc., M.D.(Lond.) \\ From the Ashford Hospital, Middle:ex
}

Myelomatosis is not an uncommon disease. It has recently attracted increasing interest on account of its accompanying biochemical disturbances and the complications which they engender. Of primary importance in this respect are certain disturbances of protein metabolism or ' para-proteinosis,' namely (I) hyperglobulinaemia ('paraproteinaemia '), (2) Bence-Jones proteinuria (' paraproteinuria') and (3) atypical amyloidosis (' paramyloidosis '), (Kolff and Dhont, 1948). Any combination of these paraproteinoses may be found in association with myelomatosis.

The term paramyloidosis was introduced by Picchini and Fabris (1930) as an alternative to ' atypical' or 'primary' amyloidosis and its use has been recommended by Apitz (1940), Ehrich (1952) and others. Paramyloid resembles true or 'secondary' amyloid in physico-chemical and staining characteristics but differs in aetiology and sites of election. Several recent excellent reviews of the two conditions are available (Watson and McIntyre, 1952; Ehrich, 1952; Wilson, 1950; Thingstad, I95I, etc.).

Unlike amyloidosis, which commonly complicates chronic suppurations, paramyloidosis is seen either in association with myelomatosis or, less commonly, as a 'primary' degenerative change. In the latter case, some proliferation of plasma cells in the marrow is commonly found.

Paramyloid may occur in the cytoplasm of myeloma cells (Dahlin, I95I) or as deposits in or adjacent to myelomata (Lichenstein and Jaffe, I947), but is not then likely to manifest itself clinically. On the other hand it may be deposited in widespread fashion throughout the body, involving chiefly the mesodermal tissues. Thus paramyloid deposition throughout the locomotor system may simulate rheumatoid arthritis (Stewart, I938; Tarr and Ferris, 1939) and involvement of the tongue, so-called ' amyloid macroglossia,' may be a dramatic development (Brunsting and

* Now of the Dept. of Medicine, University of St. Andrew.
MacDonald, 1947). Myocardial involvement may lead to heart failure, pulmonary involvement to chronic cor pulmonale, and intestinal involvement to obstructive symptoms, while deposits may occur in skin, lymph nodes, thyroid and indeed in almost any part of the body (Thingstad, 195I).

Paramyloid, although found in association with some 15 per cent. of cases of myelomatosis (Bayrd and Bennett, I95I) is still commonly recognized only at post-mortem. Awareness of the possibility, especially in the presence of unusual symptomatology, should lead to more frequent diagnosis in life.

The following case report deals with a patient in whom widespread paramyloidosis complicating myelomatosis led to rapid deterioration and death?

\section{Case Report}

A male, aged 37 years, was admitted to hospital in November I950 with a six months' history of tiring easily, thirst, polyuria, slight cough and expectoration of frothy mucoid sputum. There was no relevant previous medical, social or family history.

The different illnesses will be considered separately.

\section{Pulmonary Tuberculosis}

At the time of admission the patient was an ill-looking man with anaemia, koilonychia and thoracic kyphosis. There were bronchial breath sounds over the right upper zone. He had an evening pyrexia of $99^{\circ}$ to $100^{\circ} \mathrm{F}$.

Chest $X$-ray (November 28, 1950). 'Tuberculous infiltration of right upper lobe with some fibrosis and cavitation.'

Sputum (November 28, 1950). Culture: ' Heavy growth of tubercle bacilli.' All other examinations for tubercle bacilli were negative save one further positive culture on February 9, 195 I.

Initially there was little improvement with rest in bed only. From December 20, $195^{\circ}$ to March I4, I95 I he had a course of intramuscular strepto- 
mycin, I g. daily (total 85 g.), and oral PAS, $18 \mathrm{~g}$. daily. During this time his pyrexia settled and he put on a few pounds in weight.

Further chest $X$-ray reports: December 2i, 1950. 'Tomograms show cavitation in the right sub-apex. Three or four separate cavities appear to be present. March 27, 195I. 'Considerable improvement.'

On May 15, 195I, a right artificial pneumothorax was induced, with resulting 40 per cent. collapse, and was maintained until the last few weeks of life.

The pulmonary tuberculosis was apparently well controlled and did not appear to be in any way responsible for the subsequent downhill course.

\section{Myomelatosis}

Initial laboratory investigations showed:

November 24, I950: Hb., 9.7 g./100 ml. (66 per cent.); R.B.C., 3,100,000 per c.mm.; C.I., I.06; P.C.V., 28 per cent.; M.C.V., 90 c. $\mu$; M.C.H.C., 34.5 per cent.; W.B.C., 4,450 per c.m. Differential count: Polymorphs, 54 per cent.; eosinophils, I per cent.; lymphocytes, 36 per cent.; monocytes, 9 per cent.

E.S.R. December 7, 1950, $63 \mathrm{~mm}$. in first hour (Westergren). January $16,195 \mathrm{I}, 49 \mathrm{~mm}$. in first hour (Westergren). March 14, 1951. $60 \mathrm{~mm}$. in first hour (Westergren).

The anaemia persisted, with little change, despite large doses of vitamin $B_{12}$, crude liver extract, folic acid, iron and testosterone, and the reticulocyte count remained between 0.5 per cent. and 2 per cent. The liver and spleen were not palpable at any time and there was no lymphadenopathy.

Polyuria and albuminuria persisted throughout the illness but he was never hypertensive (B.P. remaining about $120 / 80$ ) and showed no oedema.

Renal function tests. November 29, 1950. Urinary deposit: A few granular casts and leucocytes. Protein content: I.I 5 g./1. September 26, 195I. Urinary defosit: A few leucocytes. Protein content: $0.6 \mathrm{~g} . / 1$.

Blood urea. November $23 ; 1950,27 \mathrm{mg} . / 100 \mathrm{ml}$. November 29, I950, $3 \mathrm{I} \mathrm{mg}$./ $100 \mathrm{ml}$. April 12, 195I, $46 \mathrm{mg}$./100 ml. July 20, I95 I, $47 \mathrm{mg}$./100 $\mathrm{ml}$. September 25, I95 I, $59 \mathrm{mg}$. $/ \mathrm{I} 00 \mathrm{ml}$.

Urea clearance. November 23, I950, 36 per cent. of average normal. November 29, 1950, 39 per cent. of average normal. April 12, 195 I, 35 per cent. of average normal.

In June I95 I the patient began to complain of pain in the lower back, shoulders and hands, and this spread gradually in the next few weeks to involve the whole spine and all the major and minor joints of the limbs. The spine became fixed but without change of contour. 'The peripheral $\stackrel{2}{\varkappa}^{2}$ joints became swollen and limited in movement $\mathrm{\Phi}$ and there was much muscle wasting. He developed $\stackrel{\varrho}{c}$ a nodule about $I$ in. in diameter and rubbery to $\Rightarrow$ the touch, in the right biceps tendon. Eventually he became unable to dress or feed himself ando could not get out of bed unaided. On superficialo examination he looked as if he might have the $\frac{\bar{c}}{5}$ combined effects of ankylosing spondylitis and $\stackrel{\varnothing}{\Omega}$ rheumatoid arthritis. In September I95 I he begano to complain of difficulty in swallowing, first for ${ }^{\infty}$ solids and later for fluids. His tongue enlarged? but did not protrude, and showed marginal in- $\vec{\omega}$ dentations and thickening of the frenulum. Nasal ${ }^{\omega}$ regurgitation became troublesome.

Review of the history of anaemia and non- 3 . hypertensive renal insufficiency suggested the diagnosis of multiple myelomatosis and the musculo-skeletal changes and macroglossia were considered to be typical of paramyloidosis. Pre- $\overbrace{}^{\infty}$ liminary tests on September 28, 195 I, suggestedo that this diagnosis was correct:

(I) Bence-Fones protein present in the urine.

(2) Congo Red Test: 100 per cent. extraction at음 the end of one hour.

Careful palpation of the bones showed a thickening of the inner end of the right fifth re $\vec{c}$ in the region of the costo-chondral junction a $\mathrm{d}_{\mathrm{W}}$ review of the chest X-rays showed that a rounded area of decalcification had been present there sineeo the time of admission. X-rays of skull and spine were taken but these showed no suggestive evidence of myelomatosis. Other relevant labora- $\frac{\mathrm{Q}}{\mathrm{O}}$ tory tests during the course of the illness were:

November 21, 1950, total plasma proteins, 6.45 g. per cent.; plasma albumen, 4.75 g. per cent.; plasma globulin, 1.7 g. per cent. April I2, I95 I, total plasma proteins, $6.2 \mathrm{~g}$. per cent.; plasma albumen, $4.7 \mathrm{~g}$. per cent.; plasma globulin, $\frac{0}{3}$ I.5 g. per cent. September 25, I95 I, total plasmaproteins, $5.5 \mathrm{~g}$. per cent.; plasma albumen, $3.8 \mathrm{~g} .3$ per cent.; plasma globulin, $1.7 \mathrm{~g}$. per cent. July 3I, I95 I, serum calcium, $9.8 \mathrm{mg}$. per cent. August 3, I95 I, 24-hour urinary calcium, $350 \mathrm{mg}$. September 28, I95i, electrophoretic pattern of plasma proteins, normal.* October 4, $1951, \frac{D}{0}$ sternal marrow, ' I 1.2 per cent. plasma cells, many of which are proplasmacytes.'

The patient's condition deteriorated rapidly in the last few weeks and no further investigations or 0 special treatment were considered warranted. $\mathrm{He}$ died suddenly on October 22, 1951. Ante-mortem? diagnosis:

(I) Multiple myelomatosis.

(2) Widespread paramyloidosis.

*This investigation was kindly carried out for us by Dr. Dangerfield of St. Bartholomew's Hospital. 
(3) Pulmonary tuberculosis; right sub-apical lesion, chronic, inactive.

\section{Post-mortem Findings}

\section{External Examination}

No additional abnormalities to those noted in life were found, except for a small external haemorrhoid.

\section{Internal Examination}

Skull. The skull showed generalized thinning, and in the inner surface of the right parietal bone was a round circumscribed area of soft reddishgrey tissue, $8 \mathrm{~mm}$. diameter, which had not destroyed much bone and was not adherent to the dura. No similar lesions were found elsewhere. The meninges and brain were normal and no naked eye changes were seen in the choroid plexus or pituitary body.

Spinal cord. Surrounding the cord, particularly anteriorly, was a mass of friable waxy material partly continuous with the thickened dura. Much of the material was lying free in the extradural space; it stained deeply with iodine.

Mouth. The tongue was generally enlarged and of a peculiarly firm consistency. On section, the muscle was seen to be infiltrated with grey, slightly translucent, material, which stained intensely with iodine. This was more evident in the muscles attached to the base (Fig. I). The palate appeared normal.

Neck structures. The pharyngeal wall, tonsils, fauces, larynx, trachea and oesophagus were normal. The thyroid was small but otherwise normal, and the parathyroids were of normal size. There was no lymphadenopathy. In the prevertebral muscles on each side, especially in the glonus cervicis, was a mass of soft waxy material

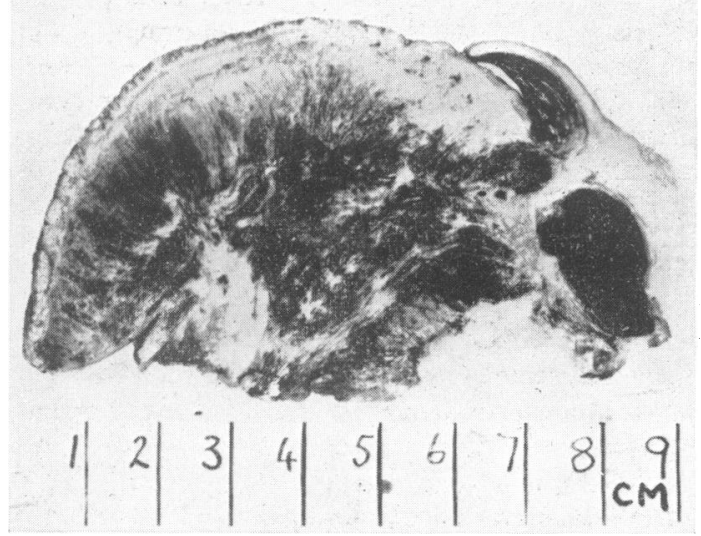

FIG. I.-Tongue. Longitudinal section. Iodine stain. The intensely black stained areas are paramyloid. which stained intensely with iodine. 'There was also generalized infiltration of the supra- and infrahyoid muscles.

Thorax. No pneumothorax or free fluid. The trachea and main bronchi were inflamed and the lower lobes of both lungs were oedematous and showed broncho-pneumonic consolidation. At the right apex was an area of fibrosis containing many small caseous partly calcified nodules, but there was no evidence of tuberculous infiltration. The diaphragm, especially near the aortic hiatus, was infiltrated with waxy material. The crura were enormously enlarged and almost completely replaced by a similar substance. The pericardial sac and heart appeared normal in all respects. Very little atheroma was present in the coronary arteries and no paramyloid could be demonstrated with iodine.

A tumour, $2.5 \mathrm{~cm}$. diameter, was present at the inner end of the fifth rib, involving the costochondral junction. From the outside it resembled the other waxy masses, but when cut across the centre was occupied by greyish red, soft, almost jelly-like material surrounded by a layer of paramyloid. Many of the intercostal muscles were partly replaced by paramyloid.

Abdomen. No free fluid and no abnormality of $\bigcirc$ the peritoneum. The stomach was dilated ando the mucosa autolyzed. The duodenum showed ac few small paramyloid deposits in the mucosa and? these became more frequent distally, the wall of the ileum being thickened in many parts. The jejunum was acutely dilated, probably as a result of interference with peristalsis in the bowel below. The large intestine appeared normal. The pancreas and adrenals were normal. The spleen (165 g.) showed small ' sago grains' which stained deeply with iodine. The liver $(\mathrm{I}, 875$ g.) showed chronic passive venous congestion but no demonstrable paramyloid. The biliary system was normal. The kidneys were small (each weighed 85 g.) the capsules stripping easily, leaving pink surfaces with numerous yellowish granules I to $2 \mathrm{~mm}$. in diameter, coalescing in places. Their cut surfaces showed reduction in cortical thickness and were mottled yellow and pink. There was some suggestion of greyish infiltration between the collecting tubules but no paramyloid was demonstable with iodine. Glomeruli could not be distinguished. The rest of the urogenital tract was normal.

No lymphadenopathy was found. The main arteries and veins were normal.

Muscles. Many muscles other than those mentioned showed infiltration with paramyloid, all staining deeply with iodine, e.g. erector spinae, pectorals, latissimus dorsi, rectus abdominis, quadratus lumborum, psoas and the vasti. In 
some cases little healthy muscle remained, as at the upper end of the rectus abdominis.

Foints. The right elbow joint showed paramyloid infiltration of the capsule and surrounding muscles, especially of the flexors, forming a tumour-like mass in the antecubital fossa. A similar condition was present round the hip and knee joints. The latter showed excess of mucinous fluid, and the internal ligaments and the connective tissues in the extrasynovial space of the intercondylar notch were infiltrated with paramyloid.

Skeleton. Apart from the right fifth rib and skull, no tumours were found. The vertebral bodies showed rather pale red marrow with scattered deeper red, jelly-like areas, especially in the first lumbar. No bony changes were seen. The left femur showed red marrow down to the lower third of the shaft, and scattered throughout it were areas similar to those in the vertebrae.

\section{Morbid Anatomical Diagnosis}

(I). Aspiration bronchopneumonia.

(2). Multiple myelomatosis.

(3). Generalized paramyloidosis.

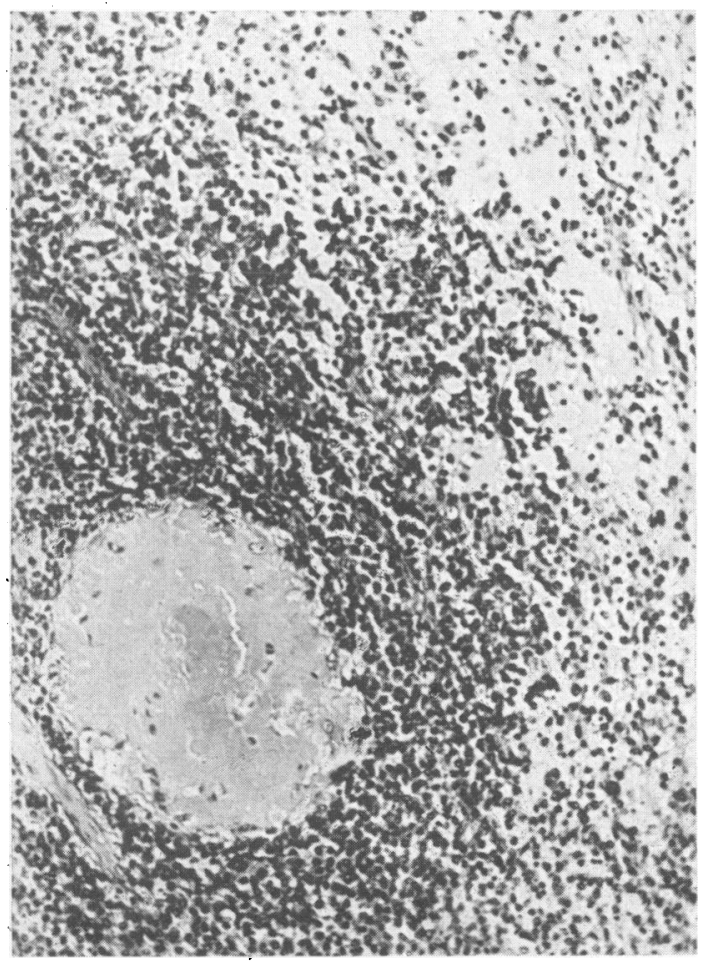

FIG. 2.-Rib tumour. van Gieson. $\times 550$. Shows paramyloid deposition in a myeloma. Relatively normal marrow is seen in the right upper corner.
(4). Fibro-caseous tuberculosis of apex of right $\frac{2}{2}$ lung.

Histology

Marrow (sternum, rib, skull, femur, lumbar $\stackrel{\overrightarrow{\vec{S}}}{\vec{f}}$ vertebrae). In all situations there was an increase $\bar{C}$ in the number of plasma cells and their precursors forming, in places, tumour islands. Post-mortem $\frac{\bar{s}}{\frac{}{\sigma}}$ changes had occurred but it could be seen that the $\underset{\complement}{\mathbb{Q}}$ cells were abnormal in morphology and showed occasional mitoses. In some areas there were small ${ }_{\rightarrow}^{\infty}$ masses of paramyloid but none could be demon-? strated inside the abnormal plasma cells (Fig. 2). $\vec{\omega}$ The largest tumour was in the rib, where con- $\sigma$ siderable bone destruction had occurred. The periosteum showed patches of paramyloid and on 3 . the inner surface of the rib was a large mass of such substance. This probably arose in an inter- $\dot{\omega}$ costal muscle since remains of striped muscle $N_{\infty}^{\infty}$ could be distinguished. Throughout the mass $\stackrel{0}{1}$ were numerous giant cells, resembling those seen $\mathrm{O}$ in degenerating muscle. Capillaries were plentiful $\stackrel{\circ}{\rightarrow}$ but mostly empty of blood.

Muscles (tongue, intercostal, diaphragm, rectus $\frac{\mathbb{Q}}{2}$ abdominis, vastus lateralis, flexors of forearm and

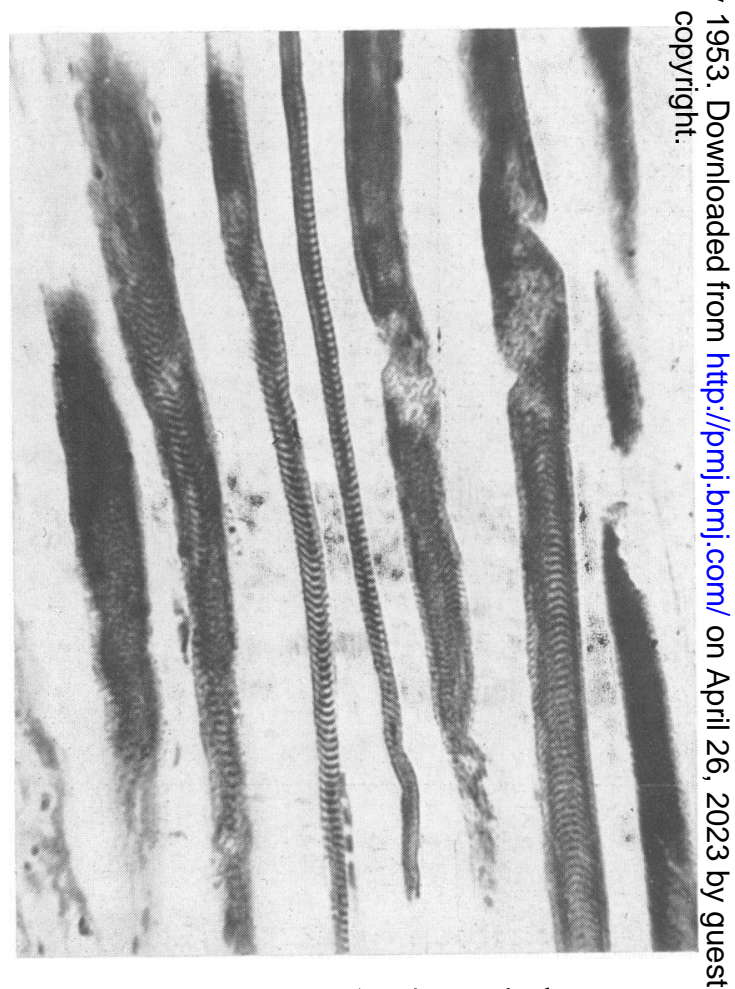

FIG. 3.-Diaphragm. Holmes's method. $\times 350$ Shows early paramyloid changes in the muscle fibres. The narrow fibre in the centre is unaffected 
pyriformis). In all situations there was a varying degree of infiltration of connective tissues and replacement of muscle by masses of paramyloid and fibrous tissue. In many places, surprisingly healthy muscle fibres could be seen in the middle of these masses. This was particularly well shown by Holmes' method (Holmes, 1947) (Fig. 3). Some areas showed collections of giant cells which at first were thought to be of muscle cell origin, but since similar cells were found in non-muscular tissues it was concluded that they were foreign body giant cells.

Foints. The joint capsules and surrounding tissues (Fig. 4) were thickened by paramyloidcontaining vascular collagen which was destroying the synovial membrane and forming masses projecting into the joint space. The free edges of these were formed of almost pure paramyloid (Fig. 5) but in some were areas of proliferated synovial cells.

Lungs. These showed chronic passive congestion and haemorrhagic oedema with diffuse bronchopneumonia of the lower lobes and fibrocaseous tuberculosis with calcification at the right

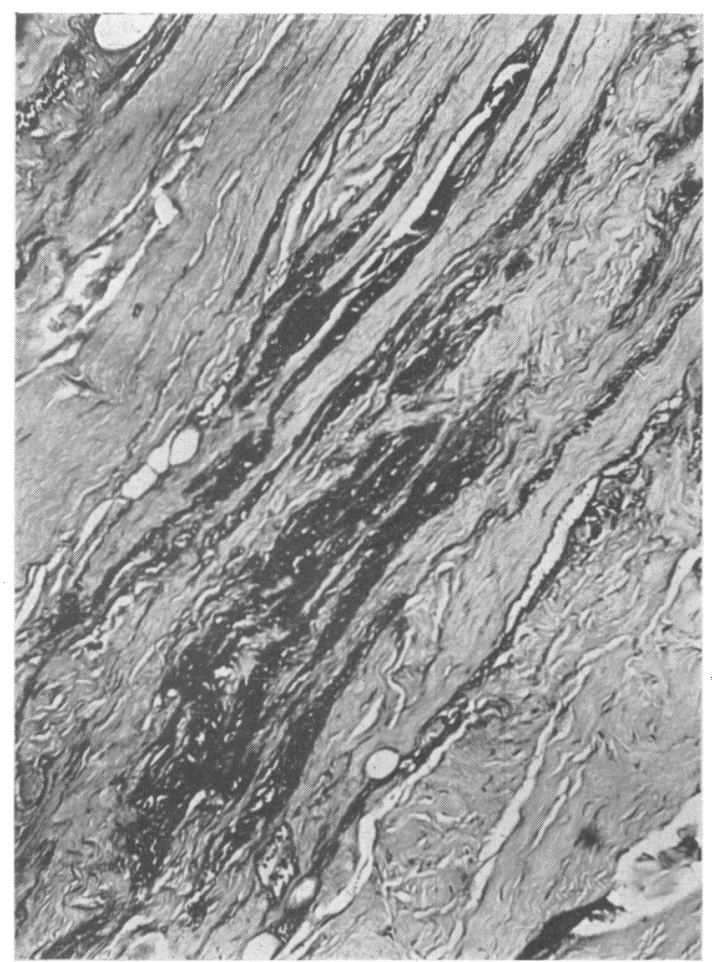

FIG. 4.-Hip-joint capsule. Methyl violet. $\times 85$. Shows partly hyalinized fibrous tissue with patches of deeply staining paramyloid material (darker areas). apex. There was little evidence of active tuberculosis and no acid-fast bacilli could be found. Many alveolar capillaries showed paramyloid changes, forming small nodules often of asteroid structure and projecting into the alveoli. They were about $50 \mu$ diameter (Fig. 6). Sometimes the remains of a capillary could be seen in the centre or to one side of the nodule. The staining with methyl violet and Congo red was patchy and where there was an asteroid structure there were alternating dark and light stripes. In some places quite large vessels ( 200 to $300 \mu$ ) were almost occluded by paramyloid. Reticulin fibrils were plentiful in the nodules and fully formed collagen could also be demonstrated.

Heart. Scattered minute patches of poorly staining paramyloid were present throughout the interstitial connective tissue replacing a few muscle fibres in places. These areas were found only after careful search with the $4 \mathrm{~mm}$. objective.

Liver. Traces of paramyloid were present in hepatic arterioles, walls of sinusoids and central veins. Abnormal plasma cells were present in the sinusoids and portal veins.

Spleen. This showed chronic passive venous

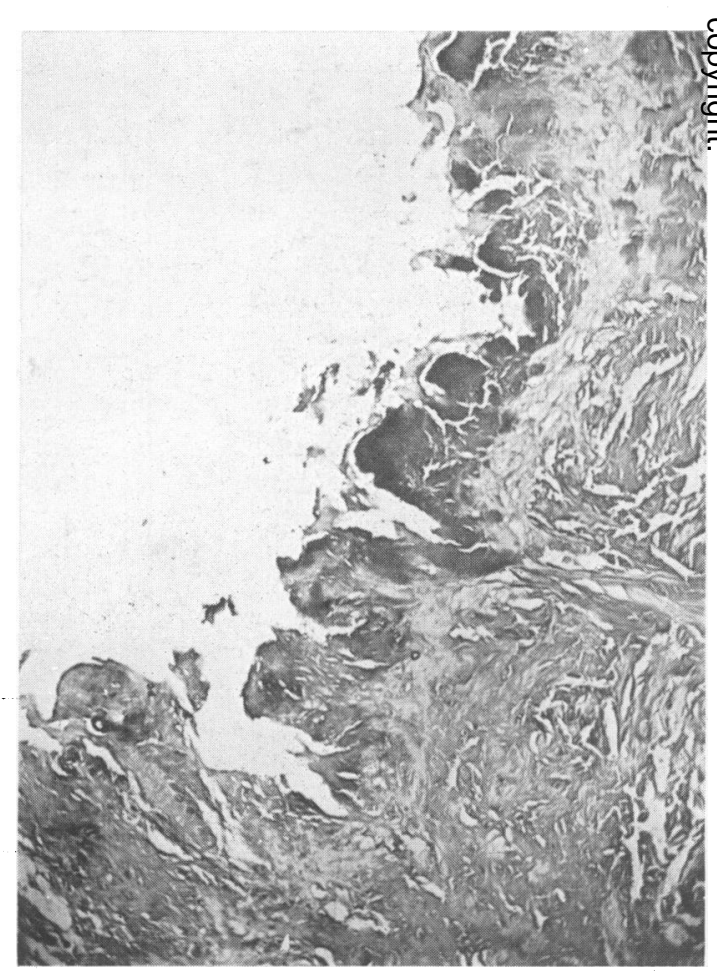

Fig. 5.-Knee joint. Methyl violet. $\times 85$. Shows replacement of synovial lining by hyalinized fibrous tissue with patches of darkly staining paramyloid. 
congestion, haemosiderosis and an abundance of plasma cells. Paramyloid was present around the Malpighian arterioles and was diffusely spread throughout the walls of the sinusoids (Fig. 7).

Pancreas and thyroid. Traces of paramyloid were present in the connective tissues and occasional capillaries.

Parathyroid. Three small nodules of paramyloid resembling those in the lung were present; otherwise the gland was normal.

Tongue. Apart from the paramyloid in the muscle, this substance was also present in the subepithelial connective tissues and walls of capillaries.

Gums and soft palate. There were traces of paramyloid deep in the subepithelial connective tissues and occasional capillary walls but none could be seen in the papillary processes. The palatal muscle was moderately infiltrated.

Oesophagus. Traces of paramyloid were present in the walls of capillaries and large amounts in the muscle coat.

Stomach. Traces of paramyloid in the capillary walls of the mucosa and in the muscularis mucosae. More was present in the muscular layer and submucous connective tissues.

Small intestine. There were generalized chronic

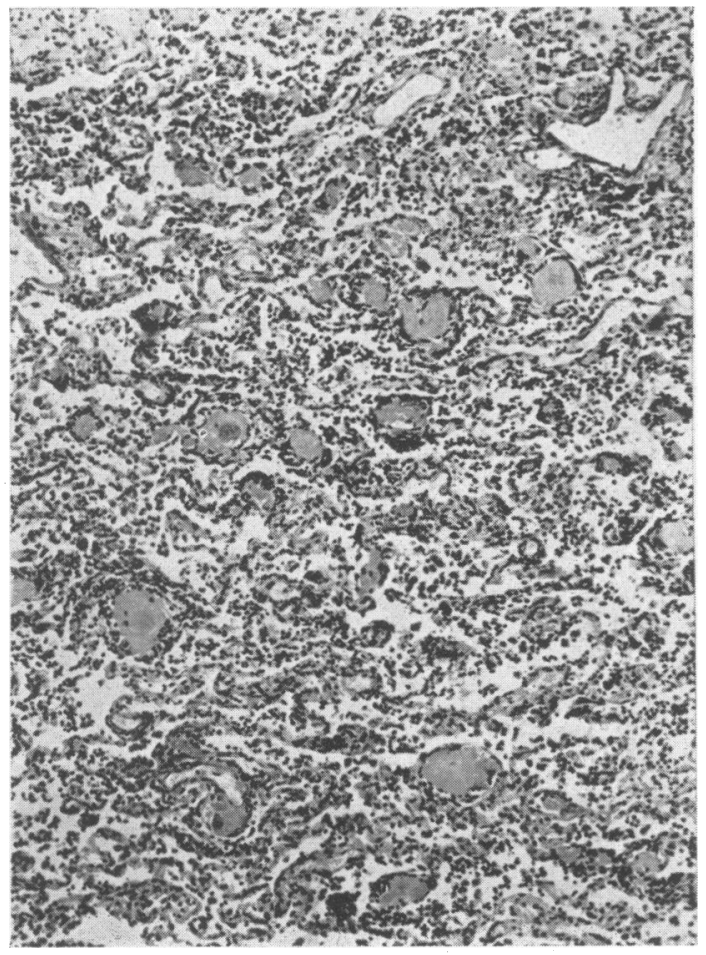

FIG. 6.-Lung. Congo red. $\times 80$. Shows multiple paramyloid nodules in the alveolar walls. inflammatory changes, with traces of paramyloid in the capillary walls of the mucosa and larger $\stackrel{\mathbb{Q}}{\varrho}$ amounts in the muscularis and submucosa.

Large intestine. Similar changes to those in the small intestine. The only evidence of paramyloid $\stackrel{\vec{P}}{+}$ in the appendix was a trace in the perineurium of $\mathrm{a}$ ?

small nerve bundle.
Submandibular salivary gland. Traces of para- $-\frac{\overline{\frac{\sigma}{5}}}{\bar{\sigma}}$

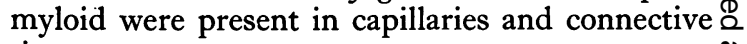
tissues.

ल

Anus. What had been thought to be a haemor- $\vec{P}$ rhoid was composed of a mass of paramyloid involving the dermis and underlying muscle and $\vec{\omega}$ connective tissues.

Kidneys. No evidence of paramyloidosis. The $\frac{2}{8}$ histological changes were those of 'myeloma 3 . kidney' (Figs. 8, 9 and ro). These are: Tubular సै atrophy with interstitial fibrosis and a varying $\omega_{\mathrm{w}}$ degree of nephrocalcinosis accompanied by tubular $\infty$ casts with intratubular epithelial reaction and $\stackrel{\infty}{y}$ formation of ' giant cells.' The casts were found 0 mainly in the distal convoluted tubules and to some extent in the proximal convoluted tubules, but 7 rarely in the loop of Henle. They stained a bright $\stackrel{\mathbb{O}}{2}$ pink with eosin and some showed a concentric $\frac{2}{\Phi}$ lamination. The central portions tended to be

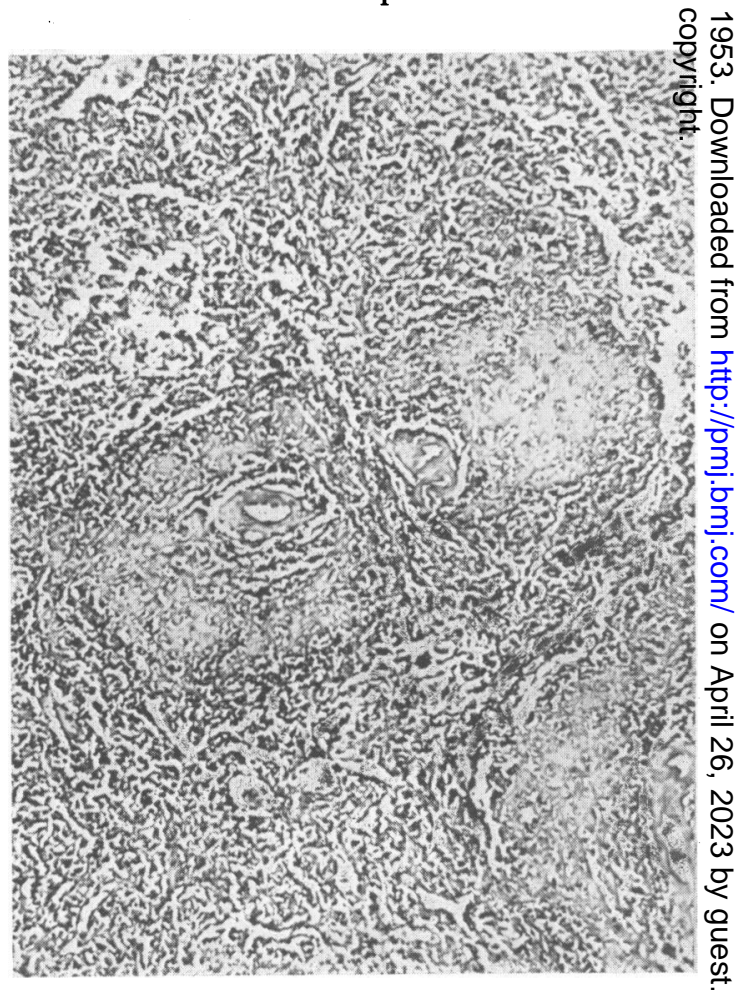

FIG. 7.-Spleen. Methyl violet. $\times$ 320. Shows hyalinization of malpighian corpuscles, staining patchily for paramyloid. 
granular or fragmented and often showed varying degrees of fibrosis and calcification. These changes were especially evident in the sections stained by the Verhoeff-van Gieson method. A characteristic feature was the presence of giant cells around the casts within the tubules. Nephrocalcinosis was not a marked feature and affected only some of the casts and damaged tubules. Many of the glomeruli were fibrosed and there was a slight degree of arteriolosclerosis. No myelomatous deposits could be found, though there was a patchy infiltration with lymphocytes and plasma cells.

Prostate. Traces of paramyloid in the muscle.

Spinal cord. No abnormality seen in the cord itself, but the dura was thickened and continuous with masses of paramyloid in its outer wall. Giant cells of foreign body type were prominent in places.

The following organs showed no trace of paramyloid: Main bronchi, gall-bladder, pituitary, adrenal, sciatic nerve, various lymph nodes, penis, testicles, seminal vesicles (though the surrounding connective tissues were affected), brain and choroid plexus.

In all situations the paramyloid consisted of masses of hyaline appearance staining a patchy pink with eosin, some areas deeper than others. Small capillaries ran in various directions and a variable number of fibroblasts were present. When stained by van Gieson's method the masses stained partly red as for collagen and partly orange, and there were parts which were more granular, corresponding to the more eosinophilic areas and those taking metachromatic dyes and Congo red. Reticulin impregnation revealed abundant fibrils in most situations. With iodine, in spite of the intense staining macroscopically, the brown colour was pale and patchy: though somewhat better in frozen sections than paraffin wax and slightly improved by acid treatment. Methyl violet stained the paramyloid metachromatically though patchily and in most places the masses appeared to consist of collagen impregnated with, or containing the remains of material staining like typical amyloid. The best staining results were obtained

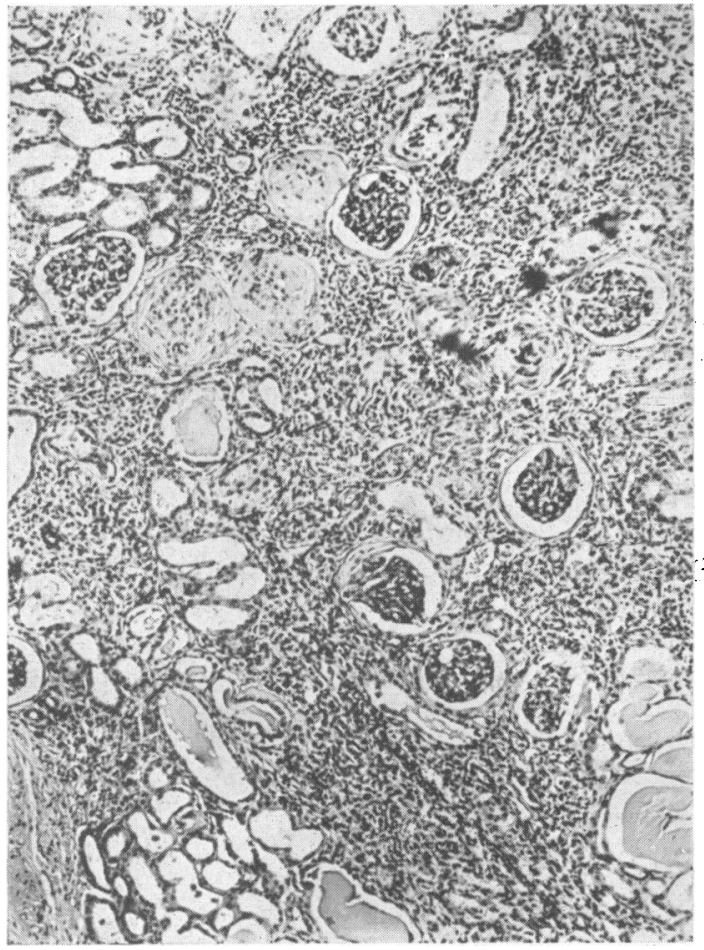

Fig. 8.-Kidney (cortex). H. and E. $\times 80$. Shows various stages in atrophy of the nephron. Note the fibrosed glomeruli.

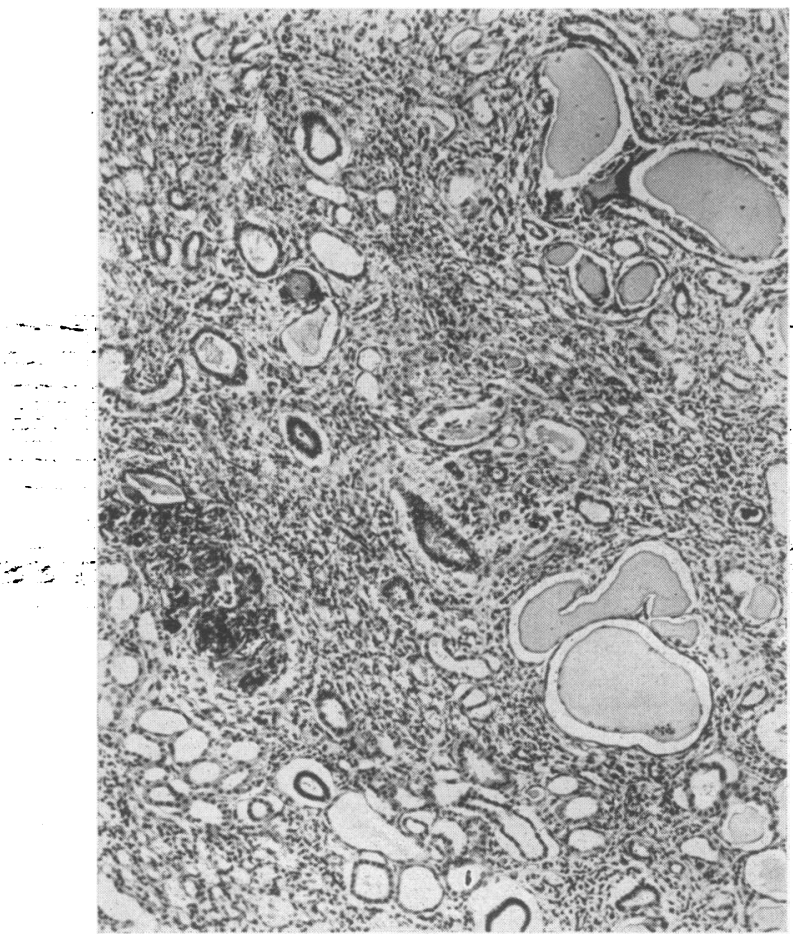

Fig. 9.-Kidney (medulla). H. and E. $\times 80$. Shows dilated tubules containing proteinous casts. One (right upper corner) shows giant-cell formation and another (left lower corner) shows disruption and early calcification. Note the fibrosis and cellular infiltration. 
from the tissues of the joints. Similarly, with Congo red, the paramyloid patches took up the stain but by no means as intensely as control sections of typical amyloid from a case of phthisis. However, the Congo red-stained material did show anisotropic properties though this bore little relation to the depth of staining. The silver method of King (1948) was tried but gave poor results and no more information than other methods. No fatty component was demonstrable in frozen sections stained with Sudan III or Sudan black. Frozen and paraffin sections stained by the periodic-acid-Schiff technique revealed no positively reacting material.

\section{Discussion}

\section{Myelomatosis}

From a review of the case notes and $\mathrm{X}$-rays it is evident that the myelomatosis was present from the time of admission to hospital, but the normochromic normocytic anaemia and non-hypertensive chronic renal insufficiency did not raise suspicion of the underlying blood dyscrasia until the more dramatic clinical manifestations of the paramyloid process brought the patient to a general medical unit. It was then possible to make the simultaneous clinical diagnoses of myelomatosis and

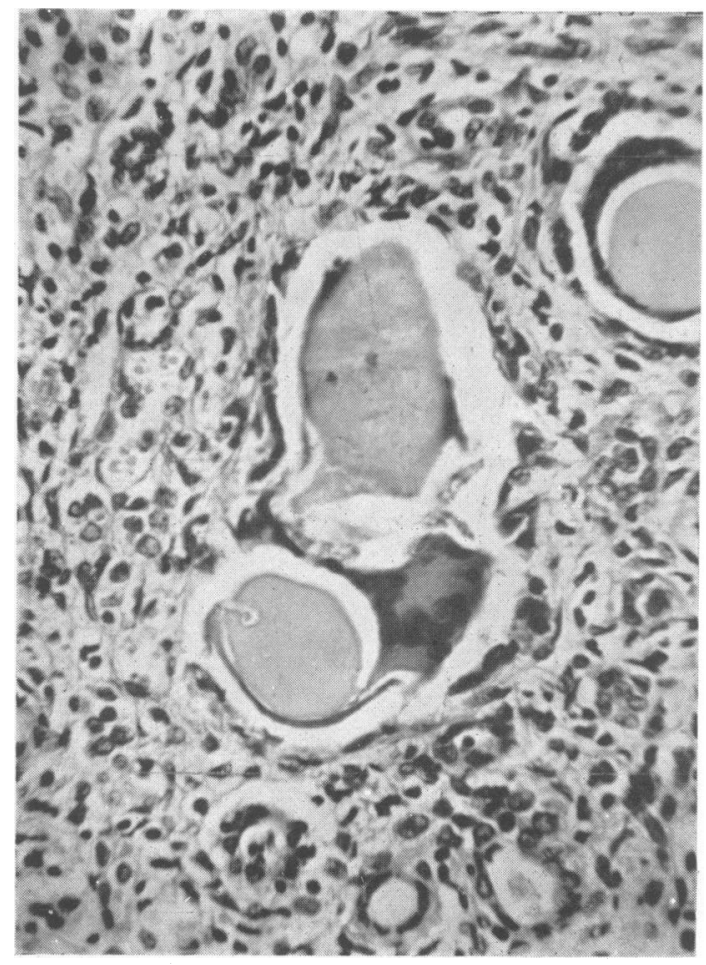

FIG. 10.-Kidney. H. and E. $\times 320$. Shows giantcell formation around a cast. paramyloidosis and to confirm them by laborator tests.

\section{Paramyloidosis}

The diagnosis of paramyloidosis was made ơn the balance of evidence, there being no certa程 method of differentiation between paramylo and amyloid. The widespread degenerative proff cess had many of the known characteristics paramyloidosis complicating myelomatosis. Mores over, the pulmonary tuberculous lesion seemed ton slight to be complicated by secondary amyloidosis though it doubtless contributed its share to the general ill health.

This case illustrates well the extensive die tribution of paramyloid that may occur in multipe. myelomatosis. The involvement of the spleen and to some extent, of the liver is not uncommon anid is commented on by several authors (e.g. Reimanso Koucky and Eklund, r935; Eisen, 1946). Thie simulation of rheumatoid arthritis is reminiscert of a case described by Stewart and Weber (19382. The myocardium is often involved (Larsen, I930; Koletsky and Stecher, 1939; Lindsay and KnorP 1945; Lindsay, 1946; Eisen, 1946; Dahlin, 1949 but in some instances, as here, microscopic ex amination is required in order to detect it (gon Huebschmann, 1907). Larsen (1930) found क्षैe posits in the muscle fibres, apparently formedo by invagination from pericapillary deposits. In the case presented here, capillary involvement was nof noticeable and the actual muscle fibres appeared to be undergoing paramyloid change. A similair appearance was seen in the skeletal muscle where the condition was in an early stage. It is possibete that this may have been either a result of in bibition from the blood stream or actual trans formation of muscle protein into paramyloid, b率 no proof exists for or against either theor Fowler (1936) categorically states that amyloid is 7 transformation product which is transported to the tissues rather than synthesized there.

The staining reactions of paramyloid may show any combination of positive and negative results with reference to iodine, Congo red and meth violet. In the present case, the results varied from tissue to tissue, but in general although the stain. ing reactions were 'typical' they were patchy and less intense than is the case in amyloidosis secondary to chronic suppurative conditions. This was so in the cases of paramyloidosis reported by Dahlio (I949).

It has been suggested (Reimann, Koucky and Eklund, 1935) that the deposits are made up of two components: (a) A ground substance which does not give the usual staining reactions of amyloid and is probably its precursor and though by Magnus-Levy in 1931 to be Bence-Jones prö 
tein, and (b) paramyloid proper which stains with methyl violet but not with Congo red or iodine. In our case the appearances are those of a heterogeneous substance showing evidence of resorption by giant cells and replacement by collagen. Giant cells are commonly found in association with paramyloid (e.g. the cases of Strauss, I933; Reimann, Koucky and Eklund, I935; Koletsky and Stecher, 1939), and were given the name of ' amyloidoclast ' by Hueter as long ago as 1910. Abundant collagen and reticulin have previously been described in the deposits in this disease (Lindsay and Knorp, 1945) and in some of the cases reported by Koletsky and Stecher there was transformation into cartilage. Hass (1942) put forward the theory that the deposits may be the result of a reaction of antigen-antibody type between a component of plasma and tissue cells, whilst Warren (1930) stated that the evidence indicated a widespread perversion of function of fibroblasts. In this connection the work of Letterer (1949) is of interest in that he showed that in experimental amyloidosis there is always mesenchymal proliferation before amyloid deposition and that in its absence amyloidosis does not result.

\section{Myeloma nephropathy}

The renal lesions associated with multiple myeloma were discussed in detail by Bell (1933), who suggested that casts of Bence-Jones protein obstruct the nephron and lead to its atrophy. He was of the opinion that giant cells which are found around the tubular casts were formed by fusion of macrophages invading from the outside, but it is now thought that they are a syncytium of tubular epithelium (Allen, I95I). The appearances in this case are in agreement with the latter. The calcification which is often found was thought by Perla and Hutner (1930) to be due to release of calcium into the blood by destruction of bone by the myelomatous tumours, but it is noteworthy that in our patient there was little evidence of bone destruction, a normal serum calcium level and, in one 24 hour estimation, a normal urinary calcium output. In cases of ' myeloma kidney,' specific glomerular lesions do not usually occur and, when present, are said to be the result of concomitant arteriosclerosis (Perla and Hutner, 1930). In our patient there was a slight degree of arteriolosclerosis but glomerular fibrosis appeared to be out of proportion to it. Moreover, there was no clinical evidence of hypertension during the year in which the Datient was observed and arteriolo- sclerosis was absent from other organs such as. liver, spleen, pancreas and adrenals. It would appear, therefore, that the glomerular fibrosis is part of the general atrophy of the nephron resulting from tubular obstruction.

\section{Summary}

The case is presented of a patient with pulmonary tuberculosis responding satisfactorily to treatment, but in whom myelomatosis was belatedly diagnosed when it became complicated with widespread paramyloidosis.

\section{Acknowledgments}

We are grateful to Dr. A. Barham Carter for permission to report this case and to the Staff of the Pathology Department, Ashford Hospital, Middlesex, for the laboratory investigations.

\section{BIBLIOGRAPHY}

ALLEN, A. C. (1951), 'The Kidney,' Grune and Stratton, New' York, p. 280.

APITZ, K. (1940), Arch. allg. Path., 306, 631.

BAYRD, E. D., and BENNETT, W. A. (195I), Med. Clin. N. America, 34, II 5 I.

BELL, E. T. (1933), Amer. F. Path., 9, 393.

BRUNSTING, L. A., and MACDONALD, I. D. (1947), Proce Mayo Clin., 22, 67 .

DAHLIN, D. C. (1949), Amer. F. Path., 25, 105.

DAHLIN, D. C. (1950), Med. Clin. N. America, 34, 1107.

EISEN, H. M. (1946), Amer. F. Med., I, 144.

EHRICH, W. E. (1952), Amer. Heart H., 43, 121.

FOWLER, W. M. (1936), F. Iowa M. Soc., 26, 98.

HASS, G. (1942), Arch. Path., 34, 92.

HOLMES, W. (r947), 'Recent Advances in Clin. Path.', J. \& A. Churchill, Ltd., London, p. 404.

voN HUEBSCHMANN, P. (1907), Virchows Arch., 87, 35 .

HUETER, C. (1910), Beitr. path. Anat., 49, 101.

KING, L. S. (1948), Amer. F. Path., 24, 1095.

KOLFF, W. J., and DHONT, J. (1948), Amer. F. Med. Sci., 215. 405 .

KOLETSKY, S., and STECHER, R. M. (1939), Arch. Path., 27, 267.

LARSEN, R. M. (1930), Amer. F. Path., 6, 147.

LETTERER, E. (1949), f. Path. Bact., 6r, 496.

LICHTENSTEIN, L., and JAFFE, H. L. (1947), Arch. Path., 44, 207.

LINDSAY, S. (1946), Amei. Heart f., 32, 419.

LINDSAY, S., and KNORP, W. F. (1945), Arch. Path., 39, 315. PERLA, D., and HUTNER, L. (1930), Amer. .. Path., 6, 285.

PICCHINI, L., and FABRIS, A. (1930), Arch. Sci. med., 54, $55 \mathrm{r}$. REIMANN, H. A., KOUCKY, R. F., and EKLUND, C. M. (1935), Am.r. F. Path., 11, 977.

STEWART, A. (1938), Quart. F. Med., 31, 21 1.

STRAUSS, A. (1933), Virchows Arch., 291, 219.

TARR, L., and FERRIS, H. W. (1939), Arch. int. Med., 64, 82c. THINGSTAD, R. (1951), Acta. med. Scand., 140, r.

WARREN, S. (1930), Amer. F. Path., 6, I6r.

WATSON, R. T. B., and MCINTYRE, J. P. (1952), Glasgow Med. $\dot{f} ., 33$, I 15.

WILSON, J. V., 'British Encyclopaedia of Medical Practice,' 2nd। edition, Vol. I, pp. 424-435. 